\title{
PENERAPAN MODEL PEMBELAJARAN BERBASIS MASALAH BERBANTUAN PERANGKAT LUNAK AUTOGRAPH UNTUK MENINGKATKAN KEMAMPUAN PEMECAHAN MASALAH MATEMATIKA BERASIS POLYA'S FOUR-STEP PROBLEM SOLVING
}

\author{
Budi Halomoan Siregar, Nurliani Manurung \\ Surel: budi_or_fuzzy@yahoo.com
}

\begin{abstract}
This research apply problem based learning model (PBM) by using autograph software in learning process of linear programming mathematics. The purpose of this study is to improve the learning process in class. Consequently, these actions can have an impact on improving problem-solving skills. This research is a classroom action research conducted on 37 students of mathematics education A 2015 in academic year 2016/2017.Furthermore, the data in this study is obtained through the process of observation and test of problem solving. The data are analyzed through three stages, namely: data reduction, data exposure, and draw conclusions. Morever, the results of this study show an increase in problem solving skills of students on indicators of understanding problems, devising a plan, carrying out the plan, and looking back the solution.
\end{abstract}

Keywords: Problem Based Learning (PBM), action research class, Autograph.

\begin{abstract}
ABSTRAK
Penelitian ini menerapkan model pembelajaran berbasis masalah (PBM) dengan memanfaat perangkat lunak autograph dalam proses belajar pemrograman linier. Adapun tujuan penelitian ini adalah untuk memperbaiki proses belajar dikelas sehingga berdampak pada peningkatan kemampuan pemecahan mahasiswa. Penelitian ini berupa penelitian tindakan kelas yang dilakukan terhadap 37 mahasiswa pendidikan matematika A 2015 pada tahun akademik 2016/2017. Data pada penelitian ini diperoleh melalui proses observasi dan pemberian tes pemecahan masalah. Selanjutnya, data tersebut dianalisis melalui tiga tahap, yaitu: reduksi data, pemaparan data, dan menarik kesimpulan. Selanjutnya, hasil penelitian ini memperlihatkan terjadinya peningkatan kemampuan pemecahan masalah mahasiswa baik pada indikator pemahaman masalah, perencanaan masalah, melaksanakan rencana, dan menyimpulkan.
\end{abstract}

Kata kunci: Pembelajaran Berbasis Masalah (PBM), PTK, Autograph.

\section{PENDAHULUAN}

Kemampuan

pemecahan

masalah adalah salah satu kecakapan tingkat tinggi yang memerlukan suatu ketrampilan khusus dalam mencari solusi atas masalah yang dihadapi dengan menggabungkan konsepkonsep dan aturan-aturan yang telah diperoleh sebelumnya, sehingga diperoleh jalan untuk mencapai suatu tujuan yang diinginkan (Dewi, 2017). Kompetensi ini sangat penting dan fundamental untuk dimiliki setiap mahasiswa. Disisilain, berdasarkan analisa hasil tes diagnose yang dilakukan terhadap mahasiswa pendidikan matematika A 2015, bahwa sebagian besar mereka belum

Dosen Jurusan Matematematika FMIPA Universitas Negeri Medan 

mampu memecahkan masalah pada topik metode grafik dengan baik. Sehingga diperlukan tindakan yang sistematis untuk meningkatkan kecakapan dalam memecahkan permasalahan matematika.

Masalah yang pertama adalah sebagian besar mahasiswa belum mampu untuk melakukan pemecahan masalah matematika dengan baik. Prosedur pemecahan masalah tidak dilakukan secara sitematis dan prosedural. Sebagai contoh, sebagian besar mereka langsung melaksanakan penyelesaian masalah sebelum memahami dan membuat rencana penyelesaian atas masalah tersebut. Selain itu, mereka juga tidak melakuan pemeriksaan terhadap jawaban yang telah diperoleh. Padahal menurut para ahli matematika, untuk memecahkan masalah matematika harus dilakukan secara sistematis dan prosedural agar proses pemecahan masalah yang dilakukan memperoleh hasil yang tepat. Seperti yang dikemukakan oleh George Polya, ada empat langkah penting yang perlu dilakukan dalam menyelesaikan permasalahan matematika, yaitu memahami masalah, merencanakan penyelesaian, melaksanakan penyelesaian, dan memeriksa kembali (Polya, 1973).

Masalah berikutnya, mahasiswa tidak memehami masalah dan merencanakan pemecahan masalah dengan baik. Mereka tidak mencari hubungan antara data yang diketahui dengan hal yang tidak diketahui (ditanyakan) pada soal. Lebih jauh lagi, sebagian besar mereka tidak menuliskan apa yang diketahui pada soal. Berdasarkan hasil wawancara yang diperoleh, ada dua alasan mengapa mereka tidak menuliskan apa yang diketahui pada soal tes tersebut, yaitu: 1) proses ini akan menghasbiskan banyak waktu, 2) mereka beranggapan tidak penting untuk menuliskan apa yang diketahui. Namun kenyataannya, mereka yang tidak merencanakan permasalahan dengan baik selalu melakukan kesalahan pada tahap penyelesaian masalah. Selain itu, mereka tidak mencoba untuk mengenali pola dan menggunakan analogi. Padahal, salah satu cara untuk menyelesaikan masalah matematika dapat dilakukan dengan mengenali pola dan memikirkan analogi dari masalah tersebut, yaitu dengan mengenali masalah yang mirip, masalah yang berhubungan, masalah yang lebih sederhana sehingga diperoleh petunjuk untuk memecahkan masalah tersebut.

Masalah yang ketiga, sebagian mereka belum mampu untuk melakukan penyelesaian masalah matematika dengan benar. Berdasarkan analisa atas lembar jawaban tes diagnosa,dapat diketahui bahwa ada tigajenis kesalahan yang dilakukan mahasiswa, yaitu 1) kesalahan dalam melakukan perhitungan (komputasi) dan kesalahan memanipulasi operasi aljabar, 2) kesalahan menggunakan data. Misalnya, mereka tidak menggunakan data yang semestinya digunakan dan kesalahan memasukkan data ke variabel 3) 
Budi Halomoan Siregar, Nurliani Manurung : Penerapan ...

kesalahan konsep. Misalnya, kesalahan menentukan rumus untuk menjawab suatu masalah.

Masalah berikutnya, mahasiswa belum mampumemeriksa kembali atas jawaban yang telah ditemukan. Mereka belum mampu mengkritisi dan melihat kelemahan dari solusi yang telah didapatkan. Berdasarkan lembar jawaban tes diagnostik, dapat diketahui bahwa mereka melakukan penyimpulan tanpa alasan pendukung yang benar. Selain itu, mereka melakukan penyimpulan tidak sesuai dengan penalaran yang logis. Lebih jauh lagi, kebanyakan mahasiswa tidak melakukan tahap pemeriksaan atas jawaban yang telah diperoleh.

Selanjutnya, berdasarkan hasil refleksi yang dilakukan peneliti yang juga selaku dosen pengampuh matakuliah pemrograman linier, dapat disimpulkan bahwa salah satu penyebab rendahnya kemampuan pemecahan masalah mahasiswa adalah karena dalam proses belajar dosen hanya fokus pada latihan soal program linier. Dosen kurang menstimulus mahasiswa agar mampu menyelesaikan masalah secara mandiri, prosedural, dan sistematis. Sehingga, kemampuan pemecahan masalah mahasiswa tidak terbangun dengan baik.

Berdasarkan uraian diatas dapat diketahui bahwa mahasiswa belum mampu memecahkan permasalahan matematika dengan baik. Kesalahankesalahan yang mereka lakukan baik berupa memahami masalah, merencanakan penyelesaian, melaksanakan penyelesaian, dan memeriksa kembali. Disisi lain, diketahui bahwa kecakapan ini sangat penting untuk dikuasai oleh mahasiswa. Sebagaimana yang dikemukakan oleh Branca (1980), bahwa pentingnya kemampuan pemecahan masalah adalah sebagai berikut: 1) kemampuan ini merupakan tujuan umum belajar matematika, 2) penyelesaian masalah yang terdiri dari prosedur, strategi, dan metode merupakan proses yang sangat utama dalam kurikulum matematika, dan 3) pemecahan asalah merupakan kecakapan dasar dalam belajar matematika.

Untuk mengatasi permasalahan diatas, peneliti sudah melakukan berbagai usaha, seperti menerapkan pembelajaran tutor sebaya dan pendekatan pembelajaran open-ended. Setelah tindakan ini dilakukan, pada dasarnya kemampuan pemecahan masalah mahasiswa sudah mengalami peningkatan. Namun,peningkatan tersebut belum menunjukkan hasil yang optimum dan belum mampu memenuhi target yang diharapkan.

Berdasarkan permasalahan dan tindakan yang telah dilakukan tersebut, masih diperlukan suatu alternatif lain agar kemampuan pemecahan masalah mahasiswa dapat meningkat sesuai dengan target yang ditetapkan.

Selanjutnya, menurut Halomoan (2014) Model pembelajaran berbasis masalah merupakan model pembelajaran yang memberikan stimulus kepada mahasiswa dengan cara memberikan masalah-masalah. Berdasarkan masalah-masalah 
tersebut, mahasiswa akan dituntut untuk berpikir logis untuk memecahkan masalah. Selain itu, menurut Izwita, dkk (2017: hal. 161) model pembelajaran berbasis masalah (Problem Based Learning) adalah suatu model inovatif yang dibangun berlandaskan teori psikologi kognitif, agar peserta didik mampu belajar aktif dan membangun pengetahuannya sendiri dengan cara memecahkan masalah autentik dengan menggunakan data-data dan informasi dan mengandalkan pengetahuan sebelumnya. Selanjutnya, menurut beliau (2017, hal 166) ada beberapa keunggulan yang dimiliki oleh model ini, yaitu: 1) model ini mampu mengembangkan kemampuan siswa untuk memecahkan masalah, 2) terjadi interaksi antara siswa, 3) peserta didik mengalami proses belajar sendiri, sehingga memberikan kepuasan tersendiri ketika mereka menemukan pengetahuan baru, 4) model ini dirancang agar terjadi peningkatan aktivitas belajar siswa, 5) membantu peserta didik untuk mengembangkan pengetahuan baru dan bertanggung jawab terhadap pembelajaran yang mereka lakukan, 6) model ini mampu mengembangkan kemampuan berpikir tingkat tinggi, seperti berpikir lebih kritis, yang dibarengi dengan kemampuan inovatif dan sikap kreatif, 7) model pemecahan masalah memberikan kesempatan kepada peserta didik agar menerapkan pengetahuan yang mereka miliki untuk memecahkan masalah nyata, 8) model ini akan melatih kemandirian peserta didik dalam belajar. Berdasarkan keunggulan-keunggulan yang terdapat padamodel pembelajaran berbasis masalah tersebut, peneliti memutuskan untuk menerapkan model ini sebagai upaya memperbaiki proses belajar di kelas. Kemudian diharapkan, dapat berdampak positif terhadap peningkatan kemampuan mahasiswa dalam memecahkan permasalahan pada topik metode grafik.

\section{METODE PENELITIAN}

Jenis penelitian ini adalah penelitian tindakan kelas (classroom action research), yang terdiri dari dua siklus. Dimana masing-masing siklus dilakukan melalui empat tahap, yaitu tahap perencanaan (planning), pelaksanaan (action), observasi (observation), dan refleksi. (Arikunto, 2010:132). Adapun subjek penelitian ini adalah mahasiswa pendidikan matematika A 2015 yang terdiri dari 37 orang. Penelitian ini dilakukan pada semester genap tahun akademik 2016/2017.

Intrumen penelitian yang digunakan untuk mengumpulkan data yaitu berupa seperangkat tes tertulis dan lembar observasi. Jenis tes tertulis yang digunakan ialah soal essay, dimana soal ini dirancang bertujuan untuk mengukur kemampuan pemecahan masalah mahasiswa mengenai permasalahan metode grafik. Sebelum Soal-soal tersebut digunakan, maka terebih dahulu soal-soal tersebut divalidasi oleh dua dosen yang ahli dalam bidang evaluasi. Selain itu, lembar 
Budi Halomoan Siregar, Nurliani Manurung : Penerapan ...

observasi dirancang untuk mengetahui sejauh mana seorang dosen dan para mahasiswa menerapkan model pembelajaran berbasis masalah selama proses belajar. Lembar observasi ini dikembangkan berdasarkan karakteristik dan sintaks model pembelajaran berbasis masalah.

Teknik analisis data yang diterapkan pada penelitian ini adalah deskriptif kualitatif dengan tahapantahapan sebagai berikut: 1) reduksi data, 2) paparan data, dan 3) menarik simpulan atau verifikasi. Reduksi data adalah bentuk analisis yang dilakukan dengan cara menggolongkan, mengarahkan, memisahkan data yang tidak diperlukan, dan mengorganisasi data. Dimana proses inidilakukan bertujuan untuk menyeleksi, menyederhanakan, memfokuskan, serta mentransformasi data mentah yang diperoleh melalui hasil observasi dan lembar jawaban mahasiswa.

Tahap kedua adalah pemaparan data. Pada tahap ini data-data yang telah direduksi sebelumnya akan dipaparkan dalam bentuk tabel, diagram, gambar, maupun narasi. Data-data diorganisir dan dikategori sehingga proses penarikan kesimpulan akan mudah dilakukan. Pada tahap ini, kemudian akan disajikan sekumpulan data mengenai kemampuan pemecahan masalah matematika mahasiswa untuk setiap indikator dan hasil observasi terhadap kegiatan dosen dan mahasiswa. Untuk menghitung persentase skor total setiap indikator ke-k kemampuan pemecahan masalah digunakan rumus berikut.

$$
\% \mathrm{STI}_{\mathrm{k}}=\frac{\operatorname{PSTI}_{\mathrm{k}}}{\operatorname{MSTI}_{\mathrm{k}}} \times 100 .
$$

Selanjutnya, ditentukan tingkat kemampuan pemecahan masalah mahasiswa dengan rumus sebagai berikut:

$$
\mathrm{SKPM}=\frac{\mathrm{s}}{\mathrm{B}_{\mathrm{i}}} \times 100,
$$

dimana SKPM adalah skor kemampuan pemecahan masalah, $\mathrm{S}$ adalah skor yang diperoleh, dan $B_{i}$ adalah skor maksimum. Setelah SKPM diperoleh, kemudian dikonversikan terhadap kriteria skor kemampuan pemecahan masalah. Adapun pedoman konversi skor kemampuan pemecahan masalah terhadap kategori diperlihatkan pada tabeldibawah ini.

TabelInterval SKPM dan Kategori KPM

\begin{tabular}{|l|l|}
\hline Rentang Nilai & \multicolumn{1}{|c|}{ Kategori } \\
\hline $0-59$ & Sangat Rendah \\
\hline $60-69$ & Rendah \\
\hline $70-79$ & Sedang \\
\hline $80-89$ & Tinggi \\
\hline $90-100$ & Sangat Tinggi \\
\hline
\end{tabular}

Selanjutnya, akan dianalisis hasil obsevasi terhadap proses pembelajaran. Data yang diperoleh akan dianalisis menggunakan rumus berikut:

$p_{i}=\frac{\text { banyak deskriptor yang tampak }}{\text { banyak deskriptor }}$. 
Dimana $\mathrm{P}_{\mathrm{i}}$ adalah hasil observasi pada pertemuan ke-i. Setelah diperoleh hasil observasi, kemudian data tersebut dikonversikan dalam bentuk kategori. Adapaun pedoman proses konversi diperlihatkan pada tabel berikut:

Tabel Interval skor pengukuran aktivitas guru

\begin{tabular}{|l|l|}
\hline Kategori & Interval Skor \\
\hline Kurang Sekali & $1,0 \leq \mathrm{P}_{\mathrm{i}}<1,5$ \\
\hline Kurang & $1,5 \leq \mathrm{P}_{\mathrm{i}}<2,5$ \\
\hline Sedang & $2,5 \leq \mathrm{P}_{\mathrm{i}}<3,5$ \\
\hline Baik & $3,5 \leq \mathrm{P}_{\mathrm{i}}<4,5$ \\
\hline Sangat Baik & $4,5 \leq \mathrm{P}_{\mathrm{i}}<5,0$ \\
\hline
\end{tabular}

Tahapan terkhir adalah menarik kesimpulan (verifikasi). Pada tahap ini data yang telah dipaparkan kemudian diverifikasi dengan cara menganalisis dan membandingkan data hasil penelitian dengan indikator keberhasilan penelitian. Apabila hasil penelitian mampu mencapai indikator keberhasilan penelitian maka penelitian ini dapat dikategorikan berhasil, dan begitu sebaliknya. Adapun indikator keberhasilan pada penelitian ini adalah sebagai berikut: 1) setidaknya $60 \%$ dari jumlah mahasiswa memiliki kemampuan pemecahan masalah dalam kategori tinggi atau sangat tinggi, 2) hasil observasi terhadap proses pembelajaran (aktivitas guru) dalam kategori baik atau sangat baik.

\section{HASIL PENELITIAN DAN PEMBAHASAN}

Kemampuan pemecahan masalah mahasiswa berdasarkan hasil tes diagnostik, tes kemampuan pemecahan masalah (TKPM) setelah tindakan siklus I dan II diberikan pada tabel dibawah ini.

Data ini diperoleh dengan cara memeriksa hasil tes diagnostik, TKPM I dan TKPM II. Selanjutnya, hasil tersebut direduksi dengan cara menggolongkan, serta saat mengelompokkannya, dan pada mengkategorikannya.

Tabel Hasil tes diagnostik, TKPM I dan TKPM I

\begin{tabular}{|l|c|c|c|c|c|c|}
\hline \multirow{3}{*}{ Kategori } & \multicolumn{2}{|c|}{ Skor Tes Diagnostik } & \multicolumn{2}{c|}{ Tes KPM Siklus I } & \multicolumn{2}{c|}{ Tes KPM Siklus II } \\
\cline { 2 - 7 } & $\begin{array}{c}\text { Jml } \\
\text { Mhsw }\end{array}$ & $\begin{array}{c}\text { Persentase } \\
\text { Mhsw }\end{array}$ & $\begin{array}{c}\text { Jml } \\
\text { Mhsw }\end{array}$ & $\begin{array}{c}\text { Persentase } \\
\text { Mhsw }\end{array}$ & $\begin{array}{c}\text { Jml } \\
\text { Mhsw }\end{array}$ & $\begin{array}{c}\text { Persentase } \\
\text { Mhsw }\end{array}$ \\
\hline Sangat Tinggi & 5 & $14 \%$ & 9 & $24 \%$ & 10 & $27 \%$ \\
\hline Tinggi & 8 & $22 \%$ & 10 & $27 \%$ & 13 & $35 \%$ \\
\hline Sedang & 15 & $41 \%$ & 12 & $32 \%$ & 10 & $27 \%$ \\
\hline Rendah & 5 & $14 \%$ & 6 & $16 \%$ & 4 & $11 \%$ \\
\hline Sangat Rendah & 4 & $11 \%$ & 0 & $0 \%$ & 0 & $0 \%$ \\
\hline
\end{tabular}


Diagram Hasil tes kemampuan pemecahan masalah

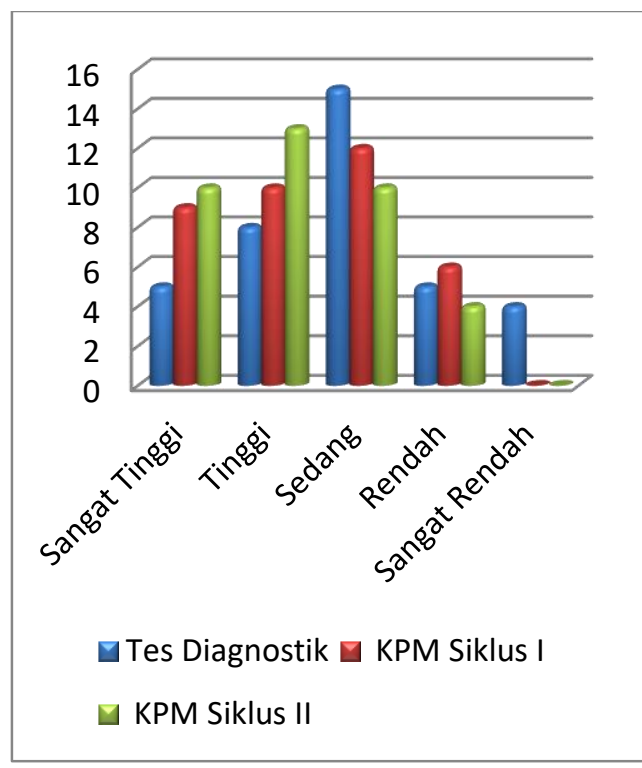

Berdasarkan tabel dan diagram diatas, dapat diketahui bahwa terjadi peningkatan jumlah mahasiswa yang memiliki kemampuan pemecahan masalah dalam kategori sangat tinggi. Dimana, pada hasil tes diagnostik hanya terdapat 5 mahasiswa yang berada pada kategori ini, namun setelah tindakan siklus I dan II dilakukan, jumlahnya meningkat menjadi 9 mahasiswa pada TKPM I dan 10 mahasiswa pada TKPM II. Begitu juga dengan trend pada kemampuan pemecahan masalah pada kategori tinggi, trend tersebut memperlihatkan peningkatan walau tidak signifikan. Dimana, terdapat 8, 10, dan 13 mahasiswa yang termasuk dalam kategori tinggipada tes diagnostik, TKPM I, dan TKPM II, secara beturut-turut. Data ini menunjukkan bahwa tindakan yang diterapkan memberikan dampak positif terhadap peningkatan kemampuan pemecahan masalah mahasiswa.

Sebaliknya, terjadi penurunan trend pada kemampuan pemecahan masalah mahasiswa yang tergolong ke dalamkategori sedang untuk ketiga hasil tes tersebut. Tabel 3 dan Diagram 1memperlihatkan bahwa terdapat 15 mahasiswa (41\%), 12 mahasiswa (32\%), dan 10 mahasiswa (27\%) pada tes diagnostik, tes KPM I, dan tes KPM II, secara berturut-turut. Berdasarkan data tersebut, dapat disimpulkan bahwa terjadi penurunan jumlah mahasiswa secara terusmenerus yang termasuk dalam kategori ini.

Disisi lain, jumlah mahasiswa yang tergolong pada kategori rendah pada ketiga tes tersebut adalah sebanyak 5 mahasiwa (14\%), 6 mahasiswa (16\%), dan 4 mahasiswa $(11 \%)$ pada tes diagnostik, tes kemampuan pemecahan masalah I (TKPM I), dan TKPM II, secara berturut-turut. Data tersebut menunjukkan terjadi trend yang fluktuatif namun tidak memperlihatkan perubahan yang cukup signifikan.

Hasil penelitian yang sangat penting untuk dipaparkan adalah hasil observasi aktivitas dosen selama proses pembelajaran. Hasil intrumen ini direduksi sehingga diperoleh data yang bermakna. Selanjutnya, dengan skor ini akan diketahui sejauh mana dosen telah menerapkan sintaks model pembelajaran berbasis masalah berbantuan autograph. 
Tabel Rata-rata skor aktivitas dosen

\begin{tabular}{|c|c|c|}
\hline \multirow{2}{*}{ Siklus } & \multicolumn{2}{|c|}{ Aktivitas Dosen } \\
\cline { 2 - 3 } & $\begin{array}{c}\text { Rata-rata } \\
\text { skor }\end{array}$ & Kategori \\
\hline Siklus I & 2,89 & Baik \\
\hline Siklus II & 3,32 & Sangat baik \\
\hline
\end{tabular}

Data pada tabel diatas menunjukkan bahwa rata-rata skor aktivitas dosen pada siklus I adalah 2,89. Dimana skor ini sudah tergolong dalam kategori baik. Hal ini memperlihatkan bahwa tahap-tahap pada sintaks model pembelajaran berbasis masalah sudah dapat diterapkan dosen dengan baik. Selanjutnya, rata-rata skor aktivitas dosen yang diperoleh pada siklus II adalah sebesar 3,32, dimana skor ini masuk ke dalam kategori sangat baik. berdasararkan data ini dapat diketahui bahwa kegiatan pembelajaran sudah dilaksanakan sesuai karakteristik dan tahapan-tahapan model tersebut.

\section{Pembahasan}

Data-data yang diperoleh pada hasil penelitian kemudian dibandingkan dengan kedua indikator keberhasilan penelitian ini. Hal ini bertujuan untuk mengetahui sejauh mana keberhasilan penelitian yang telah dilakukan. Sebelumnya, telah diketahui bahwa rata-rata skor aktivitas dosen pada siklus I adalah 2,98, yaitu dalam kategori baik,diman kategori ini sudah memenuhi salah satu indikator keberhasilan penelitian. Akan tetapi sebaliknya, hanya terdapat 19 orang atau $51 \%$ dari jumlah total mahasiswa yang termasuk dalam kategori tinggi dan sangat tinggi. Pada dasarnya data ini telah menunjukkan terjadinya peningkatan bila dibanding pada tes diagnostik. Namun perolehan ini belum mencapai indikator keberhasilan, yaitu dengan target sebanyak 60\%. Berdasarkan hasil penelitian siklus I, maka disimpulkan bahwa tindakan perbaikan akan dilanjutkan pada siklus II.

Selanjutnya, pada siklus II terjadi peningkatan pada aspek kategori aktivitas dosen yaitu sangat baik. Selain itu, pada siklus ini terdapat 23 mahasiswa (62\%) yang tergolong dalam kategori tinggi dan sangat tinggi pada aspek kemampuan pemecahan masalah. Berdasarkan data ini, dapat diketahui bahwa indikator keberhasilan penelitian telah dipenuhi.

\section{SIMPULAN}

Berdasarkan pada hasil penelitian,terdapat 23 mahasiswa (62\%) telah memiliki kemampuan pemecahan masalah dalam kategori tinggi dan sangat tinggi. Selain itu,dapat diketahui bahwa aktivitas dosen dalam melaksankan model ini dalam kategori baik dan sangat baik. Dimana kedua capaian ini telah memenuhi indikator keberhasilan penelitian. Sehingga dapat disimpulkan bahwa penelitian dengan menerapkan model pembelajaran berbasis masalah dengan berbantuan autograph dapat dikategorikan berhasil.

Peneliti menyarankan kepada para dosen pengampuh matakuliah program linier untuk menerapkan 
model pembelajaran berbasis masalah berbantuan autograph untuk meningkatkan kemampuan pemecahan masalah mahasiswa. Selanjutnya, agar penerapan model ini dapat berjalan dengan baik, maka terlebih dahuluperlu untuk memahami karakteristik mahasiswa dan materi yang akan diajarkan. Selain itu, sangat baik jika dalam proses belajar mahasiswa berdiskusi dalam kelompok kecil.

\section{DAFTAR RUJUKAN}

Arikunto, S. 2010. Prosedur penelitian. Jakarta: PT Rineka Cipta.

Halomoan B. 2014. Penerapan Problem Based Learning Pada Peningkatan Kompetensi Mahasiswa Dalam Menyelesaikan Permasalahan Limit. Jurnal Pengabdian Kepada Masyarakat LPM Unimed, ISSN: 0852-2715, Vol.20, No.78 Tahun XX, hal. 6-11.

Halomoan B. 2016. Penerapan Model Pembelajaran Discovery Learning untuk Meningkatkan Kemampuan Pemecahan Masalah Mahasiswa pada Matakuliah Himpunan dan Logika Matematika. Jurnal Generasi Kampus, ISSN: 1978869X, Vol.9, No.1,hal. 109119.

Gunantara G., Suarjana M., Ristiani P. 2014. Penerapan model pembelajaran problem based learning untuk meningkatkan kemampuan pemecahan masalah matematika siswa kelas v. Jurnal Mimbar PGSD Universitas Pendidikan Ganesha Jurusan PGSD, Vol: 2 No: 1 Tahun. 